ISSN 0258-7122

Bangladesh J. Agril. Res. 36(3) : 543-552, September 2011 Short Communication

\title{
INTEGRATED USE OF INORGANIC AND ORGANIC FERTILIZERS ON YIELD OF WHEAT IN WHEAT-T.AUS/MUNGBEAN-T.AMAN CROPPING PATTERN
}

\author{
M. A. H. BHUIYAN ${ }^{1}$, M. H. MIAN ${ }^{2}$, M. S. ISLAM ${ }^{3}$ \\ M. R. ISLAM ${ }^{4}$ AND F. ALAM ${ }^{5}$
}

Rice-wheat is one of the most important and widespread cropping systems in Asia covering about 22 million hectares of land. Rice-wheat cropping system has a capacity to produce more than 8 tons of cereal grain/ha per year removing 400 to $700 \mathrm{~kg} / \mathrm{ha}$ nutrients from soil against the use of $440 \mathrm{~kg} / \mathrm{ha}$ nutrients for ricewheat cropping system (Islam, 1995; Kamal et al., 1999; Prasad et al., 1999). The rice-wheat cropping systems, therefore, cause a considerable depletion of soil nutrients clearly posing an alarming threat to the long-term productivity. Consequently, farmers are compelled to increase fertilizer doses each year to realize the same yield levels which had been obtained with relatively low amounts of fertilizers in the past (Ahlawat et al., 1998; Islam et al., 1999; Islam, 2002). In addition, deficiencies of a number of micronutrients, such as zinc, manganese and boron, and secondary nutrients like sulphur have been reported (Jahiruddin et al., 1994; Islam et al., 1999; Uddin et al., 2002).

Despite national fertilizer recommendations in many developing countries, chemical exhaustion of soils still continues (Stoorvogel et al., 1993) as the use of inorganic fertilizer is restricted by such factors as marketing constraints and poor economic conditions of poor farmers (Laegreid et al., 2001). The farmers of Bangladesh use only about $174 \mathrm{~kg}$ nutrients/ha annually (132 kg N, 17 kg $\mathrm{P}_{2} \mathrm{O}_{5}$, $17 \mathrm{~kg} \mathrm{~K} 20,4 \mathrm{~kg} \mathrm{~S}, 2 \mathrm{~kg} \mathrm{Zn}+\mathrm{B}+$ others), as against the crop removal of about $250 \mathrm{~kg} / \mathrm{ha}$ (Islam et al., 2002). A crop production system with high yield targets cannot be sustainable unless nutrient inputs to soil are at least balanced against nutrient removal by crops (Bhuiyan et al., 1991). Proper soil fertility management, therefore, is of prime importance in an endeavor to increase crop productivity. Soil fertility in many areas of Bangladesh has already been deteriorated over the years (Karim et al., 1994; Ali et al., 1997; Ishaque et al., 1999), which is one of the reasons for stagnating, and in some cases, even reducing crop yields (Cassman et al., 1995; Panaullah et al., 1999b). Application of balanced doses of chemical fertilizers and integrated use of cowdung, ash, and chemical fertilizers gave positive yield trend of rice in longterm experiment at BRRI farm (Saleque et al., 2004).

\footnotetext{
${ }^{1}$ Senior Scientific Officer, Soil Science Division, Bangladesh Agricultural Research Institute (BARI), Joydebpur, Gazipur-1701, ${ }^{2 \& 4}$ Professor, Dept. of Soil Science, Bangladesh Agricultural University (BAU), Mymensingh, ${ }^{3}$ Former Director General, BARI, Joydebpur, Gazipur- 1701, ${ }^{5}$ Scientific Officer, Soil Science Division, BARI, Joydebpur, Gazipur- 1701, Bangladesh.
} 
Soil organic matter is an important factor to be considered in improving crop productivity. Because of the tropical climate, organic matter decomposition in Bangladesh soils is high. The need for proper soil organic matter management needs due attention in view of the low organic matter status of our soils (Ali et al., 1997). The study was carried out to find out the integrated use of inorganic and organic fertilizers on yield and yield attributes of wheat.

A pattern based experiment was launched in rabi season of 1999 at the Bangladesh Agricultural University Farm, Mymensingh, Bangladesh to find out the integrated use of inorganic and organic fertilizers on yield and yield attributes of wheat grown as the first crop. The study was continued in the same field having the same layout for three consecutive years. The physical and chemical characteristics of the soil of the experimental site are presented in Table I.

Table 1. Physical and chemical characteristics of the soils of experimental field.

\begin{tabular}{lc}
\multicolumn{1}{c|}{ Characteristics } & Analytical data \\
\hline Mechanical fractions (USDA system) & \\
a) Sand $(2.00-0.05 \mathrm{~mm}) \%$ & 33 \\
b) Silt $(0.05-0.002 \mathrm{~mm}) \%$ & 47 \\
c) Clay $(<0.002 \mathrm{~mm}) \%$ & 20 \\
Textural class & Silty clay loam \\
pH & 6.9 \\
CEC $(\mathrm{cmol} / \mathrm{kg}$ soil) & 11.7 \\
Organic carbon $(\%)$ & 1.01 \\
Total N $(\%)$ & 0.10 \\
Available P $(\mathrm{kg} / \mathrm{g})$ & 10.0 \\
Exchangeable K $(\mathrm{cmol} / \mathrm{kg}$ soil) & 0.13 \\
Available S $(\mu \mathrm{g} / \mathrm{g})$ & 14.0 \\
Available $\mathrm{Zn}(\mu \mathrm{g} / \mathrm{g})$ & 1.71 \\
Available B $(\mu \mathrm{g} / \mathrm{g})$ & 0.20 \\
\hline
\end{tabular}

The experiment comprised of four treatments for the first crop (wheat), eight for the second crop (T. Aus and Mungbean) and 12 for the 3rd crop (T. Aman); and was laid out in a randomized complete block design with three replications. The plot size was $5 \mathrm{~m} \times 4 \mathrm{~m}$. The application rates of $\mathrm{N}, \mathrm{P}, \mathrm{K}, 5, \mathrm{Zn}$, and $\mathrm{B}$ for wheat (first crop of the pattern) were $80,20,50,10,1$, and $1 \mathrm{~kg} / \mathrm{ha}$, respectively, for moderate yield goal (MYG) and 120, 30, 75, 15, 2, and $2 \mathrm{~kg} / \mathrm{ha}$ for high yield goal (HYG). 
The fertilizer doses for moderate yield goal (MYG) and high yield goal (HYG) of wheat were decided on soil test basis (STB) using Fertilizer Recommendation Guide (BARC, 1997). For the treatment $T_{4}$, the fertilizer dose was same as of $\mathrm{T}_{2}$ but decomposed cowdung $5 \mathrm{t} / \mathrm{ha}$ (fresh weight basis) was applied before sowing wheat. One-third of urea $\mathrm{N}$ and full doses of P, K, 5, Zn, B were applied as basal at final land preparation. The remaining $2^{\text {nd }}, 3^{\text {rd }}$ urea were top-dressed in two equal splits at the time of 1st irrigation (17-22 DAS) and at $2^{\text {nd }}$ irrigation (50 DAS). Seeds of wheat @ 120 kg seed ha ${ }^{-1}$ were sown on 30 November 1999, 28 November 2000 and 03 December 2001 with row to row distance $20 \mathrm{~cm}$. Harvesting of wheat crop was done in March. Yield data were collected from $4 \mathrm{~m}$ x $3 \mathrm{~m}$ area of each plot. Grains and straw were sun-dried and weighed adjusting at $14 \%$ moisture content and yields were converted to t/ha. The parameters on spike/meter, grains/spike, tillers/hill, grains/panicle, 1000grain weight (g), grain yield (t/ha) and straw yield (t/ha) were recorded.

Treatment combinations.

\begin{tabular}{|c|c|c|}
\hline $\begin{array}{l}\text { 1st crop-Rabi } \\
\text { (Wheat) }\end{array}$ & $\begin{array}{l}\text { 2nd crop-Kharif-1 } \\
\text { (T. Aus/Mungbean) }\end{array}$ & $\begin{array}{l}\text { 3rd crop-Kharif-1 } \\
\text { (T. Aman) }\end{array}$ \\
\hline \multirow[t]{3}{*}{$\begin{array}{l}\mathrm{T}_{1} \text { : Control } \\
\left(\mathrm{N}_{0} \mathrm{P}_{0} \mathrm{~K}_{0} \mathrm{~S}_{0} \mathrm{Zn}_{0} \mathrm{~B}_{0} \mathrm{~kg} / \mathrm{ha}\right)\end{array}$} & $\mathrm{T}_{1.1}:$ T. Aus: Control & $\mathrm{T}_{1.1}$ : Control \\
\hline & $\mathrm{T}_{1.2}:$ Mungbean: Control & $\begin{array}{l}\mathrm{T}_{1.2} \text { : Mungbean residue not } \\
\text { incorporated + Control }\end{array}$ \\
\hline & & $\begin{array}{l}\mathrm{T}_{1.2 .2} \text { : Mungbean residue } \\
\text { incorporated + Control }\end{array}$ \\
\hline \multirow[t]{3}{*}{$\begin{array}{l}\mathrm{T}_{2} \text { : Nutrient rates on soil } \\
\text { test basis (MYG) } \\
\left(\mathrm{N}_{80} \mathrm{P}_{20} \mathrm{~K}_{50} \mathrm{~S}_{10} \mathrm{Zn}_{1} \mathrm{~B}_{1}\right. \\
\mathrm{kg} / \mathrm{ha})\end{array}$} & $\begin{array}{l}\mathrm{T}_{2.1}: \mathrm{T} \text {. Aus } \\
\text { NPKS (MYG) } \\
\left(\mathrm{N}_{60} \mathrm{P}_{12} \mathrm{~K}_{32} \mathrm{~S}_{5} \mathrm{~kg} / \mathrm{ha}\right.\end{array}$ & $\begin{array}{l}\mathrm{T}_{2.1}: \text { NPKS (MYG) } \\
\left(\mathrm{N}_{60} \mathrm{P}_{12} \mathrm{~K}_{32} \mathrm{~S}_{5} \mathrm{~kg} / \mathrm{ha}\right.\end{array}$ \\
\hline & $\begin{array}{l}\mathrm{T}_{2.2}: \text { Mungbean } \\
\text { PKS } \\
\left(\mathrm{P}_{10} \mathrm{~K}_{13} \mathrm{~S}_{5} \mathrm{~kg} / \mathrm{ha}\right. \\
\text { + Inoc. }\end{array}$ & $\begin{array}{l}\mathrm{T}_{2.2} \text { : Mungbean residue not } \\
\text { incorporated }+\mathrm{NPKS} \\
(\mathrm{MYG})\left(\mathrm{N}_{60} \mathrm{P}_{12} \mathrm{~K}_{32} \mathrm{~S}_{5} \mathrm{~kg} / \mathrm{ha}\right)\end{array}$ \\
\hline & & $\begin{array}{l}\mathrm{T}_{2.2 .2} \text { : Mungbean residue } \\
\text { incorporated + Reduced } \\
\text { dose of inorganic fertilizers } \\
(\mathrm{MYG})\left(\mathrm{N}_{32} \mathrm{P}_{9} \mathrm{~K}_{5} \mathrm{~S}_{3} \mathrm{~kg} / \mathrm{ha}\right.\end{array}$ \\
\hline \multirow[t]{2}{*}{$\begin{array}{l}\mathrm{T}_{3} \text { : Nutrient rates on soil } \\
\text { test basis (FIYG) } \\
\left(\mathrm{N}_{120} \mathrm{P}_{30} \mathrm{~K}_{75} \mathrm{~S}_{15} \mathrm{Zn}_{2} \mathrm{~B}_{2}\right. \\
\mathrm{kg} / \mathrm{ha}\end{array}$} & $\begin{array}{l}\mathrm{T}_{3.1}: \mathrm{T} \text {. Aus } \\
\text { NPKS (HYG) } \\
\left(\mathrm{N}_{90} \mathrm{P} 18 \mathrm{~K} 48 \mathrm{~S} 7.5 \mathrm{~kg} \text { had }\right)\end{array}$ & $\begin{array}{l}\text { T31: NPKS (HYG) } \\
\left(\mathrm{N}_{90} \mathrm{P}_{18} \mathrm{~K}_{48} \mathrm{~S}_{7.5} \mathrm{~kg} / \mathrm{ha}\right)\end{array}$ \\
\hline & $\begin{array}{l}\mathrm{T}_{3.2} \text { : Mungbean } \\
\text { PKS }\left(\mathrm{P}_{10} \mathrm{~K}_{13} \mathrm{~S}_{5} \mathrm{~kg} / \mathrm{ha}\right. \\
\text { +lnoc. }\end{array}$ & $\begin{array}{l}\mathrm{T}_{3.2 .1} \text { : Mungbean residue not } \\
\text { incorporated + NPKS } \\
(\mathrm{HYG})\left(\mathrm{N}_{90} \mathrm{P}_{18} \mathrm{~K}_{48} \mathrm{~S}_{7.5} \mathrm{~kg} / \mathrm{ha}\right.\end{array}$ \\
\hline
\end{tabular}




\begin{tabular}{|c|c|c|}
\hline & & $\begin{array}{l}\mathrm{T}_{3.2 .2}: \text { Mungbean residue } \\
\text { incorporated + Reduced } \\
\text { dose of inorganic fertilizers } \\
(\mathrm{HYG})\left(\mathrm{N}_{59} \mathrm{P}_{15} \mathrm{~K}_{17} \mathrm{~S}_{5} \mathrm{~kg} / \mathrm{ha}\right)\end{array}$ \\
\hline \multirow[t]{3}{*}{$\begin{array}{l}\mathrm{F}_{4} \text { : Nutrient rates on soil } \\
\text { test basis }(\mathrm{MYG}) \\
\left(\mathrm{N}_{80} \mathrm{P}_{20} \mathrm{~K}_{50} \mathrm{~S}_{10} \mathrm{Zn}_{1} \mathrm{~B}_{1}\right. \\
\mathrm{kg} / \mathrm{ha}) \\
+\mathrm{CD}(5 \mathrm{t} / \mathrm{h}) \text { on wet } \\
\text { weight basis }\end{array}$} & $\begin{array}{l}\mathrm{T}_{4.1}: \mathrm{T} \text {. Aus } \\
\text { NPKS (MYG) } \\
\left(\mathrm{N}_{60} \mathrm{P}_{12} \mathrm{~K}_{32} \mathrm{~S}_{5} \mathrm{~kg} / \mathrm{ha}\right.\end{array}$ & $\begin{array}{l}\mathrm{T}_{4.1}: \mathrm{NPKS}(\mathrm{MYG}) \\
\left(\mathrm{N}_{60} \mathrm{P}_{12} \mathrm{~K}_{32} \mathrm{~S}_{5} \mathrm{~kg} / \mathrm{ha}\right. \\
+\mathrm{CD}(5 \mathrm{t} / \text { ha on wet weight } \\
\text { basis }\end{array}$ \\
\hline & $\begin{array}{l}\mathrm{T}_{4.2}: \text { Mungbean } \\
\mathrm{PKS} \\
\left(\mathrm{P}_{10} \mathrm{~K}_{13} \mathrm{~S}_{5} \mathrm{~kg} / \mathrm{ha}\right. \\
+ \text { Inoc. }\end{array}$ & $\begin{array}{l}\mathrm{T}_{4.2 .1} \text { : Mungbean residue not } \\
\text { incorporated }+\mathrm{NPKS}^{\mathrm{N}} \\
\text { (MYG) }\left(\mathrm{N}_{60} \mathrm{P}_{12} \mathrm{~K}_{32} \mathrm{~S}_{5} \mathrm{~kg} / \mathrm{ha}\right) \\
+\mathrm{CD}(5 \mathrm{t} / \mathrm{ha}) \text { on wet weight } \\
\text { basis }\end{array}$ \\
\hline & & $\begin{array}{l}\mathrm{T}_{4.2 .2} \text { : Mungbean residue } \\
\text { incorporated } \\
\text { + Reduced dose of inorganic } \\
\text { fertilizers } \\
(\mathrm{MYG})\left(\mathrm{N}_{31} \mathrm{P}_{9} \mathrm{~K}_{3} \mathrm{~S}_{3} \mathrm{~kg} / \mathrm{ha}\right. \\
+\mathrm{CD}(5 \mathrm{t} / \mathrm{ha} \text { on wet weight } \\
\text { basis }\end{array}$ \\
\hline
\end{tabular}

The collected data were analyzed statistically and Duncan's Multiple Range Test (DMRT) using a computer IRRISTAT and M-stat package programmes (Freed, 1992) adjudged the means. The correlation co-efficient and regression analysis were done for different variables wherever needed using Microsoft EXCEL programme 1997.

Grain yield of wheat was significantly influenced due to fertilizer and manure treatments in all three years during 1999-2002 and the highest grain yield was always found with the application of recommended NPKSZn fertilizers for HYG (Table 2). In 1999-2000, the highest grain yield of $3.35 \mathrm{t} /$ ha was obtained with recommended NPKSZnB (HYG) fertilizers. However, the grain yield recorded with NPKSZnB (MYG) fertilizers + cowdung (CD) was statistically identical to NPKSZnB (HYG) fertilizers. The yield recorded with NPKSZnB (MYG) fertilizers without cowdung failed to produce comparable yield with NPKSZnB (HYG). In 2000- 2001 trial, the highest grain yield (3.19 t/ha) was found with NPKSZnB (HYG) fertilizers was statistically similar to NPKSZnB (MYG) fertilizers plus cowdung. In 200 1-2002 trial, the highest grain yield (2.85 t/ha) noted with NPKSZnB (HYG) fertilizers was significantly higher over NPKSZnB (MYG) with and without cowdung.

The treatment of NPKSZnB (MYG) + CD gave high yield compared to NPKSZnB (MYG) treatment. The increased yield was due to release of nutrients 
from CD to the growing wheat plants. Similar result was observed by other workers (Zhu HongXun e al., 1995; Hegde, 1998; Khatun, 1999; Panaullah et al., 1999a; Rahman, 2001). The grain yield was lower in 2002 than 2000 and 2001 probably due to high temperature prevailing during the crop season and delayed sowing in December. Mungbean residue incorporation had advantage over mungbean residue removal (Fig. 1).

Table 2. Effects of integrated use of fertilizers and manure on the yields of wheat (cv. Kanchan) in Wheat-T. Aus/Mungbean-T. Aman rice cropping pattern.

\begin{tabular}{|c|c|c|c|c|c|c|c|c|}
\hline \multirow[b]{2}{*}{ Treatment } & \multicolumn{4}{|c|}{ Grain yield (t/ha) } & \multicolumn{4}{|c|}{ Straw yield (t/ha) } \\
\hline & $\begin{array}{l}1999- \\
2000\end{array}$ & $\begin{array}{l}2000- \\
2001\end{array}$ & $\begin{array}{l}2001- \\
2002\end{array}$ & Mean & $\begin{array}{l}1999- \\
2000\end{array}$ & $\begin{array}{l}2000- \\
2001\end{array}$ & $\begin{array}{l}2001- \\
2002\end{array}$ & Mean \\
\hline $\mathrm{T}_{1}$ :Control & $1.02 \mathrm{c}$ & $0.94 \mathrm{c}$ & $0.66 c$ & $0.87 d$ & $2.93 \mathrm{~b}$ & $2.90 \mathrm{c}$ & $2.35 \mathrm{~b}$ & $2.73 c$ \\
\hline $\begin{array}{l}\mathrm{T}_{2}: \mathrm{NPKSZnB} \\
\text { (MYG) }\end{array}$ & $2.89 \mathrm{~b}$ & $2.75 b$ & $2.60 \mathrm{~b}$ & $2.75 c$ & $5.99 a$ & $5.62 b$ & $5.52 \mathrm{a}$ & $5.71 \mathrm{~b}$ \\
\hline $\begin{array}{l}\mathrm{T}_{3}: \mathrm{NPKSZnB} \\
\text { (HYG) }\end{array}$ & $3.35 \mathrm{a}$ & $3.19 a$ & $2.85 a$ & 3.13a & 7.34a & $6.71 \mathrm{a}$ & $5.94 \mathrm{a}$ & $6.66 \mathrm{a}$ \\
\hline $\begin{array}{l}\mathrm{T}_{4}: \mathrm{NPKSZnB} \\
(\mathrm{MYG})+\mathrm{CD}\end{array}$ & 3.23ab & $3.06 a$ & $2.69 \mathrm{~b}$ & $2.99 \mathrm{~b}$ & $6.08 \mathrm{a}$ & $5.89 \mathrm{~b}$ & 5.63a & $5.87 \mathrm{~b}$ \\
\hline$\overline{C V(\%)}$ & 8.6 & 5.7 & 2.9 & 2.6 & 17.4 & 4.8 & 4.7 & 4.7 \\
\hline
\end{tabular}

In a column, the figure(s) having same letter are not significantly different at $5 \%$ level of probability by DMRT

MYG: Moderate Yield Goal, HYG: High Yield Goal

NPKSZnB (MYG): 80 kg N, 20 kg P, 50 kg K, 10 kg S, 1 kg Zn, 1 kg B/ha

NPKSZnB (HYG): 120 kgN, 30kg P, 75 kg K, 15kg S, 2kg Zn, 2kg B/ha

CD: Cowdung, 5 t/ha1 (wet weight basis)

In all three years, the highest wheat straw yield was recorded with NPKSZnB (HYG) fertilizers (Table 2). The highest straw yields (7.34 t/ha) in the first year trial, $6.71 \mathrm{t} / \mathrm{ha}$ in second year trial and $5.94 \mathrm{t} / \mathrm{ha}$ in third year trial were noted with NPKSZnB (HYG) fertilizers.

The highest straw yields recorded in the $1^{\text {st }}$ and $3^{\text {rd }}$ year trials for NPKSZnB (HYG) were comparable with the straw yields for NPKSZnB (MYG) with and without cowdung, but in the second year trial, the straw yield was significantly higher for NPKSZnB (HYG) than for NPKSZnB (MYG) with or without cowdung. The straw yield recorded with NPKSZnB (MYG) with cowdung was statistically identical to NPKSZnB (MYG) without cowdung. Figure 1 displayed a beneficial residual effect of mungbean residue on wheat straw yield during second and third year trials. 


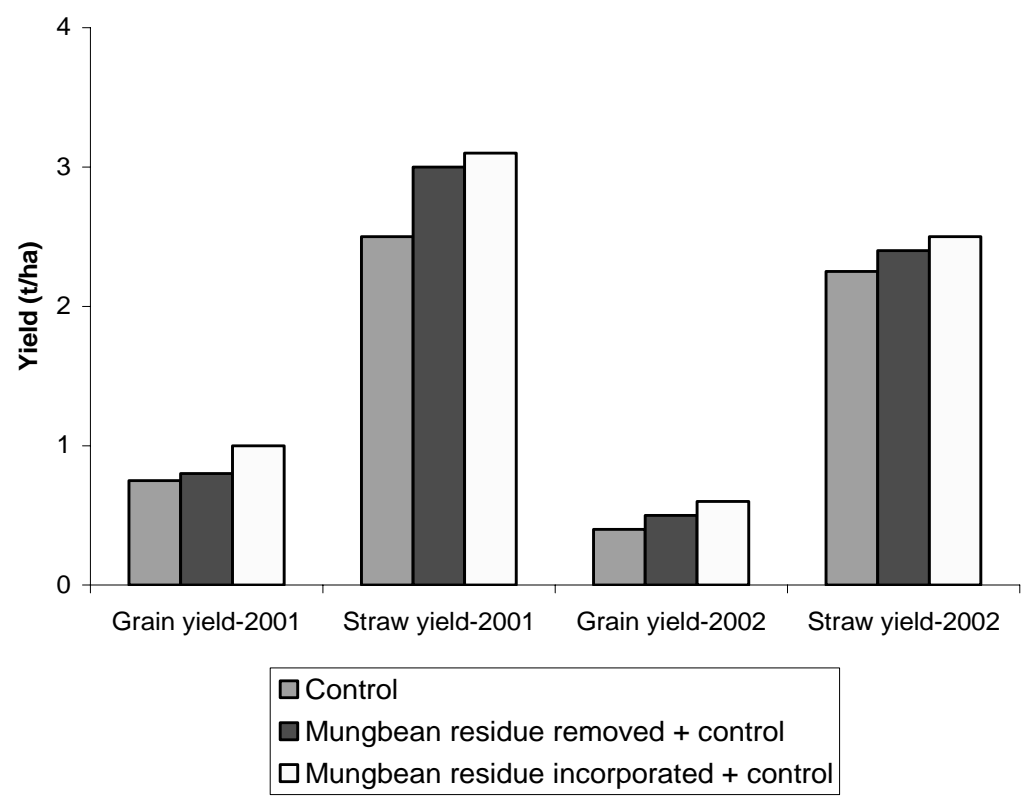

Fig. 1. Yield of wheat due to mungbean residue incorporation in $\mathrm{T}_{1}$ treatment.

Spike/ $\mathrm{m}^{2}$ was significantly influenced by different treatments (Table 3 ). Spikes $/ \mathrm{m}^{2}$ of the crop ranged from 159 to 316 in 1 st year trial, 143 to 311 in $2^{\text {nd }}$ year trial and 156 to 303 in $3^{\text {rd }}$ year trial over the treatments. The treatment $T_{3}$ which received nutrients (NPKSZnB) for HYG recorded the highest number of spikes $/ \mathrm{m}^{2}$ (316 in 1999-2000,311 in 2000-2001 and 303 in 2001-2002), which was statistically identical to those when fertilizers were applied for MYG plus cowdung in all the years.

The fertilizer and manure treatments also significantly influenced the number of grains/spike over control (Table 3). No significant differences in grains/spike were observed in different treatments except control in $1^{\text {st }}$ and $3^{\text {rd }}$ years. In the $2^{\text {nd }}$ year, NPKSZnB (HYG) recorded significantly higher grains/spike than NPKSZn (MYG) with or without cowdung. The HYG treatment received high amount of NPKSZnB and consequently resulted in high number of grains/spike as compared to MYG and MYG + CD treatments. However, addition of cowdung to NPKSZnB for MYG $\left(\mathrm{T}_{4}\right)$ had positive effect on grains/spike only in $2^{\text {nd }}$ year. Thousand-grain weights were not influenced by different treatments used in the experiment (Table 3). However, thousand-grain weights were relatively higher in control treatment. The 1000 -grain weight is a genetic character, thus, nutrient management seldom changes it. 
Table 3. Effects of integrated use of fertilizers and manure on the yield attributes of wheat (cv. Kanchan) in Wheat-T. Aus/Mungbean-T. Aman rice cropping pattern.

\begin{tabular}{|c|c|c|c|}
\hline Treatment & Spike/m² (no.) & Grains/spike (no.) & 1000-grain wt (g) \\
\hline \multicolumn{4}{|l|}{ 1999-2000 } \\
\hline $\mathrm{T}_{1}$ : Control & $159 c$ & $20.2 b$ & 46.7 \\
\hline $\mathrm{T}_{2}: \mathrm{NPKSZnB}(\mathrm{MYG})$ & $295 b$ & $34.4 \mathrm{a}$ & 45.6 \\
\hline $\mathrm{T}_{3}: \mathrm{NPKSZnB}(\mathrm{HYG})$ & $316 a$ & 36,la & 44.4 \\
\hline $\mathrm{T}_{4}: \mathrm{NPKSZnB}(\mathrm{MYG})+\mathrm{CD}$ & $306 a b$ & $35.8 a$ & 45.3 \\
\hline $\mathrm{CV}(\%)$ & 2.8 & 2.8 & 1.9 \\
\hline \multicolumn{4}{|l|}{ 2000-2001 } \\
\hline $\mathrm{T}_{1}$ : Control & $143 b$ & $17.7 \mathrm{~d}$ & 46.5 \\
\hline $\mathrm{T}_{2}: \mathrm{NPKSZnB(MYG)}$ & $302 a$ & $34.3 c$ & 45.3 \\
\hline $\mathrm{T}_{3}: \mathrm{NPKSZnB}(\mathrm{HYG})$ & 31 la & 37.3a & 44.8 \\
\hline $\mathrm{T}_{4}: \mathrm{NPKSZnB}(\mathrm{MYG})+\mathrm{CD}$ & 303a & $36.9 \mathrm{~b}$ & 45.3 \\
\hline CV (\%) & 4.9 & 0.6 & 0.5 \\
\hline \multicolumn{4}{|l|}{ 2001-2002 } \\
\hline $\mathrm{T}_{1}$ : Control & $156 c$ & $15.7 \mathrm{~b}$ & $41.9 \mathrm{a}$ \\
\hline $\mathrm{T}_{2}: \mathrm{NPKSZnB(MYG)}$ & 293b & $32.0 \mathrm{a}$ & $39.8 b$ \\
\hline $\mathrm{T}_{3}: \mathrm{NPKSZnB}(\mathrm{HYG})$ & 303a & $32.7 \mathrm{a}$ & $38.4 \mathrm{~b}$ \\
\hline $\mathrm{T}_{4}: \mathrm{NPKSZnB}(\mathrm{MYG})+\mathrm{CD}$ & 295ab & $32.2 \mathrm{a}$ & 39.3b \\
\hline CV (\%) & 1.5 & 4.0 & 2.5 \\
\hline
\end{tabular}

In a column, the figure(s) having same letter are not significantly different at $5 \%$ level of probability by DMRT.

MYG: Moderate Yield Goal, HYG: High Yield Goal

NPKSZnB (MYG): 80 kg N, 20 kg P, 50 kg K, 10 kg S, 1 kg Zn, 1 kg B/ha

NPKSZnB (HYG): 120 kgN, 30kg P, 75kg K, 15kg S, 2kg Zn, 2kg B/ha

$\mathrm{CD}$ : Cowdung, $5 \mathrm{t} / \mathrm{ha}$ (wet weight basis)

Correlation coefficient among the plant characters revealed that the grain yield of wheat was positively correlated with straw yield, spikes $/ \mathrm{m}^{2}$ and grains/spike, but grain yield was negatively correlated with 1000-grain weight in all the years (Table 4). 
Table 4. Correlation matrix among the plant characters of wheat $(n=12)$.

\begin{tabular}{l|l|l|l|l|l}
\hline \multirow{2}{*}{ Characters } & \multirow{2}{*}{ Year } & \multicolumn{4}{c}{ Correlation coefficient (r value) } \\
\cline { 3 - 7 } & & Straw yield & Spike/m & Grains/spike & 1000 -grain wt \\
\hline \multirow{2}{*}{ Grain yield } & 2000 & $0.893^{* *}$ & $0.974^{* *}$ & $0.976^{* *}$ & $-0.790^{* *}$ \\
& 2001 & $0.980^{* *}$ & $0.984^{* *}$ & $0.991^{* *}$ & $-0.906^{* *}$ \\
& 2002 & $0.988^{* *}$ & $0.996^{* *}$ & $0.989^{* *}$ & $-0.845^{* *}$ \\
\hline Straw yield & 2000 & - & $0.914^{* *}$ & $0.852^{* *}$ & $-0.851^{* *}$ \\
& 2001 & - & $0.962^{* *}$ & $0.964^{* *}$ & $-0.922^{* *}$ \\
& 2002 & - & $0.990^{* *}$ & $0.982^{* *}$ & $-0.884^{* *}$ \\
\hline Spikes/m & 2000 & - & - & $0.983^{* *}$ & $-0.736^{* *}$ \\
& 2001 & - & - & $0.981^{* *}$ & $-0.908^{* *}$ \\
& 2002 & - & - & $0.990^{* *}$ & $-0.835^{* *}$ \\
\hline Grains/spike & 2000 & - & - & $-0.706^{* *}$ \\
& 2001 & - & - & $-0.918^{* *}$ \\
& 2002 & - & - & $-0.824^{* *}$ \\
\hline
\end{tabular}

**Significant at $1 \%$ level

The grain and straw yield data revealed that significant yield improvement was achieved due to NPKSZnB fertilizers for HYG. The highest grain and straw yields of 3.13 and 6.66 t/ha (mean of 3 years) showing 266 and $145 \%$ yield increase, respectively, over control were obtained with the application of NPKSZnB (HYG) fertilizers $\left(\mathrm{T}_{3}\right)$. On the other hand, the lowest grain yield of $0.87 \mathrm{t} / \mathrm{ha}$ and straw yield of $2.73 \mathrm{t} / \mathrm{ha}$ were recorded in unfertilized control $\left(\mathrm{T}_{1}\right)$ plots. Inclusion of cowdung with NPKSZnB for MYG contributed a little to the grain and straw yield increase (8.7\% high grain and $2.8 \%$ high straw over NPKSZnB for MYG fertilizers).

\section{References}

Ahlawat, I.P.S., M. Ali, R.L. Yadav, J.V.D.K. Kumar Rao, T.J. Rego and R.P. Singh. 1998. Biological nitrogen fixation and residual effects of summer and rainy season grain legumes in rice and wheat cropping systems of the Indo-Gangetic Plain. In: Residual Effects of Legumes in Rice and Wheat Cropping Systems of the IndoGangetic Plain (Kumar Rao, J.V.D.K., Johansen, C. and Rego, T.J. eds.). ICRISAT, Inter. Crops Res. Inst. for the Semi-Arid Tropics, Patancheru 502 324, Andhra Pradesh, India. Oxford \& IBH Publishing Co. Pvt. Ltd. pp. 31-54.

Ali, M.M., S.M. Shaheed and D. Kubota. 1997. Soil degradation during the period 19671995 in Bangladesh. II. Selected chemical characters. Soil Sci. Plant Nutr 43: 879890.

BARC. 1997. Fertilizer Recommendation Guide. Published by BARC, Dhaka, Bangladesh. 
Bhuiyan, N.J., A.L. Shah and G.M. Panaullah. 1991. Effect of NPK fertilization on the grain yield of transplanted rice and soil fertility-A long-term study. Bangladesh $\mathrm{J}$. Soil Sci. 22(1\&2): 41-50.

Cassman, K.G., S.K. de Datta, D.C. 01k, J. Alcantra, M. Seson, J. Descalsota and M. Dizon. 1995. Yield decline and the nitrogen economy of long-term experiment on continuous, irrigated rice system in the tropics. pp. 181-222. In: Lal, R. and Stewart, B.A. (Eds.). Soil Management: Experimental basis for sustainability and environmental quality. Lewis Publisher, London, U.K.

Freed, R.D. 1992. MSTAT-C. Crop and Soil Science Department, Michigan State University, USA.

Hegde, D.M. 1998. Integrated nutrient management effect on rice (Oryza sativa)-wheat (Triticum aestivum) system productivity in sub-humid ecosystem. Indian J. Agric. Sci. 68(3): 144-148.

Ishaque, M., G.M. Panaullah, N.I. Bhuiyan and P.K. Saha. 1999. Integrated nutrient management with inorganic fertilizers and green/organic manure for Boro-T.Aman rice cropping pattern. In: Proc. Nat. Workshop on Integrated Nutrient Management for Crop Production and Soil Fertility. (Islam, M.F., Choudhury, D.A., Panaullah, G.M., Miah, M.M.U., Rijpma, T. and Haque, M.F. eds.). 24-25 Mar, 1998, Gazipur. pp. 111-126.

Islam, M.R. 2002. Effects of different levels of chemical and organic fertilizers on growth, yield and protein content of wheat. Online J. Biol. Sci. 2(5): 304-306.

Islam, M.R., M.N. Huda and M. Jahiruddin. 2002. Determination of critical limit of sulphur in rice soils of Bangladesh. Proc. 17th World Congr. Soil Sci. 14-21 Aug, 2002, Bangkok, Thailand p.1530.

Islam, M.R., M.S. Islam, M. Jahiruddin and M.S. Hoque. 1999. Effects of sulphur, zinc and boron on yield, yield components and nutrient uptake of wheat. Pakistan J. Sci. and Ind. Res. 42(3): 137-140.

Islam, M.S. 1995. Integrated nutrient management approach for fertilizer recommendation in cropping patterns under different soil conditions of Bangladesh. Proc. Inter-Congr. Conf. of Comm. IV. 1-3 Dec, 1992, Dhaka, Bangladesh. pp. 147-156.

Jahiruddin, M., M.N. Islam, M.A. Hashem and M.R. Islam. 1994. Influence of sulphur, zinc and boron on yield and nutrient uptake of BR2 rice. Prog. Agric. 5(1): 61-67.

Kamal, A.M.A., M.R. Islam and B.L.D. Chowdhury. 1999. Growth performance, protein content and nutrient uptake by modern varieties of rice under irrigated condition in Bangladesh. Thai J. Agric. Sci. 32(1): 105-1 10.

Karim, Z., M.M.U. Miah and S. Razia. 1994. Fertilizer in the national economy and sustainable environmental development. Asia Pacific J. Environ. Dev. 1: 48-67.

Khatun, M.R. 1999. Integrated nutrient management for wheat-T.Aus-T.Aman cropping pattern under Old Brahmaputra Floodplain AEZ of Bangladesh. M.S. Thesis, Dept of Soil Sci., Bangladesh Agril. Univ., Mymensingh, Bangladesh. 
Laegreid, M., O.C. Bockman and 0. Kaarstad. 2001. Agriculture, Fertilizers and the Environment. CAB International, Wallingford, UK.

Panaullah, G.M., M. Ishaque and A.L. Shah. 1999b. Integrated nutrient management with inorganic fertilizers and organic manures for Potato-T.Aus-T.Aman rice cropping pattern. (Islam, M.F., Choudhury, D.A., Panaullah, G.M., Miah, M.M.U., Rijpma, T. and Haque, M.F. eds.). In: Proc. Nat. Workshop on Integrated Nutrient Management for Crop Production and Soil Fertility. 24-25 Mar, 1998, Gazipur. pp. 147-152.

Panaullah, G.M., M.A. Saleque, M.J. Abedin and M. Ishaque. 1999a. Integrated nutrient management with inorganic fertilizers, crop residues and organic manure for Wheat/ Mungbean-T.Aman rice cropping pattern. (Islam, M.F., Choudhury, D.A., Panaullah, G.M., Miah, M.M.U., Rijpma, T. and Haque, M.F. eds.). in: Proc. Nat. Workshop on Integrated Nutrient Management for Crop Production and Soil Fertility. 24-25 Mar, 1998, Gazipur. pp. 171-182.

Prasad, R., S.N. Sharma and S. Singh. 1999. Summer mung for sustaining rice-wheat cropping system. Bulletin of National Professor's Unit, Division of Agron., Indian Agril. Res. Inst., New Delhi-110012. India, pp. 1-11.

Rahman, M.A. 2001. Integrated use of fertilizer and manure for crop production in wheat-rice and rice-rice cropping patterns. Ph.D. Thesis, Dept of Soil Sci., Bangladesh Agril. Univ., Mymensingh, Bangladesh.

Saleque, M.A., M.J. Abedin, N.I. Bhuiyan, S.K. Zaman and G.M. Panaullah. 2004. Longterm effects of inorganic and organic fertilizer sources on lowland rice. Field Crop Res. 86: 53- 65.

Stoorvogel, J.J., E.M.A. Smaling and B.H. Janssen. 1993. Calculating soil nutrient balances in Africa at different scales. I. Supra-national scale. Fert. Res. 35: 227-235.

Uddin, M.K., M.R. Islam, M.M. Rahman and S.M.K. Alam. 2002. Effects of sulphur, zinc and boron supplied from chemical fertilizers and poultry manure to wetland rice (cv. BRRI dhan 30). Online J. Biol. Sci. 2(3): 165-167.

Zhu HongXun, Zhang Xiang and Sun ChunHe. 1995. Effect of different fertilizer combinations on yield of wheat and maize and quality of wheat. Acta Agricultural Boreali-Sinica 10(2): 100-105. 